\title{
Malignant Laryngeal Neoplasm
}

National Cancer Institute

\section{Source}

National Cancer Institute. Malignant Laryngeal Neoplasm. NCI Thesaurus. Code C7484.

A primary or metastatic malignant neoplasm involving the larynx. The majority are carcinomas. 